\title{
NMES
}

New Middle Eastern Studies

ISSN: 2051-0861

Publication details, including guidelines for submissions:

https://journals.le.ac.uk/ojs1/index.php/nmes

\section{The Question of Palestine and the Muslim World}

Author(s): Abdullah al-Ahsan

To cite this article: al-Ahsan, Abdullah (2018) "The Question of Palestine and the Muslim World”, New Middle Eastern Studies 8 (2), pp. 84-106.

Online Publication Date: 21 January 2019

\section{Disclaimer and Copyright}

The NMES editors make every effort to ensure the accuracy of all the information contained in the journal. However, the Editors and the University of Leicester make no representations or warranties whatsoever as to the accuracy, completeness or suitability for any purpose of the content and disclaim all such representations and warranties whether express or implied to the maximum extent permitted by law. Any views expressed in this publication are the views of the authors and not the views of the Editors or the University of Leicester.

Copyright New Middle Eastern Studies, 2019. All rights reserved. No part of this publication may be reproduced, stored, transmitted or disseminated, in any form, or by any means, without prior written permission from New Middle Eastern Studies, to whom all requests to reproduce copyright material should be directed, in writing.

\section{Terms and Conditions}

This article may be used for research, teaching and private study purposes. Any substantial or systematic reproduction, re-distribution, re-selling, loan or sub-licensing, systematic supply or distribution in any form to anyone is expressly forbidden.

The publisher does not give any warranty express or implied or make any representation that the contents will be complete or accurate or up to date. The accuracy of any instructions, formulae and drug doses should be independently verified with primary sources. The publisher shall not be liable for any loss, actions, claims, proceedings, demand or costs or damages whatsoever or howsoever caused arising directly or indirectly in connection with or arising out of the use of this material. 


\title{
The Question of Palestine and the Muslim World
}

\author{
Abdullah al-Ahsan*
}

\begin{abstract}
The question of Palestine (and the city of Jerusalem) is a core issue that remains at the centre of the Muslim mind in our time. This is because most Muslims feel that the Zionist Movement created the State of Israel in Palestine after World War II by depriving the local population of their fundamental right to exist in their ancestral homeland. The global Zionist Movement conspired, resorted to terrorist tactics and executed an ethnic cleansing campaign to create the State of Israel. The Zionists first secured the support of British politicians and then the American leaders in favour of their search for an exclusive Jewish state covering the entirety of the former British Mandate of Palestine. Although the Palestinians - like Muslims in various parts of the world - quickly developed a national consciousness in the inter-war period and tried to protect their fundamental rights, they were no match for the Zionists who had already secured the support of major powers of the globe (e.g. Britain and the US). Later, Israel managed to obtain UN membership in its third attempt with the commitment to allow all Palestinians to return to their ancestral home. But in practice, Israel has ignored all UN resolutions regarding the Israeli-Palestinian conflict. Israel has gradually developed a legal framework to deny the citizenship rights of the original population of Palestine and continues to build new Jewish settlements by demolishing Palestinian homes. While the Palestinians continue to suffer under Israeli repression, the OIC (Organization of Islamic Cooperation) and most Muslim governments have largely abandoned the Palestinian cause of liberation. This, in turn, frustrates much of the Muslim youth around the world - fuelling fundamentalism and extremism.
\end{abstract}

Keywords: United Nations; League of Nations; Organization of Islamic Cooperation (OIC); Zionism; Israel; Palestinian nationalism; the Muslim World

\section{Introduction}

Decades ago, the late Palestinian intellectual activist and Columbia Professor Edward Said (1992) wrote a work entitled "the Question of Palestine". Said strongly defended the legitimacy of the rights of Palestinians in their homeland. Of course, Said was prompted to write on this subject due to ongoing Israeli occupation of Palestine and Israel's continuous manipulation of history to justify its armed occupation. Our aim here is to relate this question to the Muslim community at large. Why and how the question of Palestine has become such a salient feature in contemporary Muslim political discourse? Why are Muslims all over the

\footnotetext{
*Abdullah al-Ahsan; Department of Political Science and International Relations, Istanbul Şehir University, Orhantepe Mahallesi, Turgut Özal Bulvarı, No:21, Kartal, Istanbul 34865, Turkey. Email: abdullahilahsan@sehir.edu.tr.
} 
world so attached to this question? In this article, we examine this issue in the context of the activities of the Organization of Islamic Cooperation (OIC).

The presence of the Al-Aqsa mosque in Jerusalem, the capital city of Palestine, generally draws the attention of common Muslims. The name Al-Aqsa appears in the Qur'an (17: 1) and Muslims consider this mosque their third most important shrine in the world. In 1931, in a conference held in Jerusalem, Muslim leaders from various parts of the world expressed in clear terms the Muslim attachment to Jerusalem and Palestine. In 1969, the OIC came into existence in response to an arson attack on the Al-Aqsa Mosque in Jerusalem by a Zionist activist. All these point to a strong Muslim attachment to Jerusalem.

Historically, the Jews and Muslims lived peacefully in Palestine since the $7^{\text {th }}$ century $\mathrm{CE}$ when Muslims liberated the territory from the Byzantine Empire. Earlier, the Jews were expelled from the territory, first by the Assyrians, then by the Babylonians, and finally by the Romans. According to most Palestinian nationalists, however, the area was populated by the Canaan people and foreign invasions and wars had hardly made any major demographic impact in the region. On their part, the Jews retained an emotional attachment with the area because of the central role of Jerusalem in their history and numerous Biblical references to the territory. According to the Bible, Jewish leaders David and Solomon, both considered prophets of God by Muslims, established a kingdom in the area around $1000 \mathrm{BC}$. In the $7^{\text {th }}$ century, the territory became a Muslim majority area mainly through conversion: there is no evidence of forced conversion or any substantial migration of Muslim populations from the outside of the territory.

Under Muslim rule, the Jews generally enjoyed peace and comfort, made significant contributions to socio-economic life and flourished during the early centuries of Islamic civilization. Many of them, according to an Israeli author, were "aged folk, drawn to the Holy Land by promptings of piety, came to prey and to die, to be buried there, rather than to live and work," settled back in Palestine (Tsur 1969: 19). The Jews suffered along with Muslims when the Christian Crusaders captured Jerusalem in 1099 and they were only able to return to Jerusalem in 1187 when Salahaddin Ayyubi (1138 - 1193) liberated the city from the Crusaders. About 5,000 Jews lived in Palestine during the Napoleonic invasion at the end of the $18^{\text {th }}$ century. Emperor Napoleon I reportedly invited European Jews to settle in Palestine during the short-lived French rule. Starting from early $19^{\text {th }}$ century, European Jews began to migrate to Palestine. ${ }^{1}$ It was not because of the slow and gradual migration of these Jews that Israel was born; however. Instead, the state of Israel owes its birth to the Zionist Movement that emerged in Europe at the end of the $19^{\text {th }}$ century. In this article, we address the issue of the establishment of Israel before we address the question of Palestine because, in our view, it is the state of Israel in Palestine that has prompted the rise of the Palestinian question in international politics today.

\section{Zionism and the Birth of Israel}

Zionism was born as an ideology near the end of the $19^{\text {th }}$ century during the age of European nationalist fervor. Pressed by the longstanding anti-Semitism of many European societies and the growth of various forms of race-oriented ultra-nationalism in the continent, European Jews began to feel threatened and start seeking to establish their own homeland. They began 
to conceive of a state for Jews in the modern world; and many of them wanted the proposed state to be located in modern Palestine, claiming legitimacy from the Torah. In 1896, a Hungarian Jew, Theodor Herzl, wrote The Jewish State arguing for a Jewish national home in the modern world of nations. A year later, the World Zionist Organization met in Switzerland and resolved to establish "a homeland for Jews in Palestine." It is interesting to note that although most indigenous Palestinians were not aware of the Zionist plan, most religious oriented Jews opposed this idea of a Jewish state in Palestine. ${ }^{2}$ The secular nationalist Jews, however, established Zionist organizations and institutions to promote the idea arguing that this was a humanitarian cause on the basis that they believed that they were subjected to oppression and persecution in Europe because of their race and religion.

Edward Said (1992: XXXVII) accurately pointed that, "[t]he first wave of Zionist colonialists reached the shores of Palestine in the early 1880s." This was due to the growth of anti-Semitic nationalist fervor in Europe at the end of the $19^{\text {th }}$ century; Jews were considered non-nationals in most European countries. The number of Jews in Palestine increased to an estimated 80,000 just before World War I. During the War, however, the number declined to about 55,000, which represented approximately 5 percent; Muslims constituted 80 percent while Christians constituted about 15 percent of the total population.

The Jewish Colonization Association was established in 1891 with the help of wealthy Jewish business magnates from all over the world financing the acquisition of lands in Palestine. The Association needed an established government to pursue its agenda, but had none. The founder of Zionism, Theodor Herzl (1860-1904), first approached the German Kaiser Wilhelm II for his consent to establish a Chartered Land Development Company to be operated by Zionists under a German protectorate, but the Kaiser declined. Then he directly approached the Ottoman Sultan Abdulhamid II (r. 1876-1908) with a lucrative offer of buying Palestine for European Jews to settle. Although the Sultan was in desperate need of funds, he declined the offer saying, according to Herzl (1960: 378), that "I cannot sell even a foot of land, for it does not belong to me, but to my people." The Sultan clearly wished to point that the Ottomans were not a colonial power in the area. Then, the Zionists turned to the British Empire for support.

By 1904, the leadership of the movement passed into the hands of a Russian Jew, Chaim Weizmann, who had migrated to England the same year. Although a chemist by profession, Weizmann was also a skillful diplomat. He established personal relationships with most British politicians and as early as 1914, when the Ottomans joined the Central Powers, he argued that:

[W]e can reasonably say that should Palestine fall within the British sphere of influence, and should Britain encourage Jewish settlement there, as a British dependency, we could have in twenty to thirty years a million Jews out there, perhaps more; they would develop the country, bring back civilization to it and form a very effective guard for the Suez canal (Weizmann 1949: 149).

The above statement reflects Weizmann's perception of civilization, the British interest in the area, and the "white man's burden" mentality of British politicians. He gradually exploited these discourses very effectively. 
In 1917, the British captured Palestine from the Ottomans with the help of some local Arab tribes (mainly the Hashemites). Soon, the Zionists received a pledge in the form of a personal letter written to a wealthy businessperson, which came to be known as the Balfour Declaration, expressing support for the "establishment in Palestine of a national home for the Jewish people." Arthur J. Balfour, the British Foreign Secretary who claimed to have become a Zionist, following a discussion with Chaim Weizmann, ${ }^{3}$ was in no position to announce such a commitment on behalf of the British Empire. Yet he made the declaration as if Palestine was his personal property in sharp contrast with the approach of the Ottoman Sultan Abdulhamid II. He seemed to have been persuaded by some wealthy British and non-British European Zionists. It is because of such secretive manipulation by Zionists that many Muslims today believe that the state of Israel came into existence out of a conspiracy. It is interesting to note that, at the same time, other British officials made similar commitments about the same territory to the Hashemite Sharif Hussein through what came to be known as the Hussein-McMahon correspondence, and to the French, the Sykes-Picot Agreement.

The issue was then taken to the Paris Peace Conference (1919) where the Zionists had sent a powerful delegation composed of influential individuals mainly from Britain and the US. It should be noted that no Palestinian Jews were included in this delegation. The Palestinian Arabs had not sent a delegation to the Conference either. President Woodrow Wilson of the United States, who was welcomed in Paris as the "savior" and "prophet of peace," and who was also aware of the Zionist demands for a Jewish state in Palestine, categorically opposed the idea of establishing the state of Israel in Palestine. Incidentally, however, the President fell ill and was not able to personally pursue his proposals for selfdetermination. Also, because of the defeat of his Democratic Party in the elections, the US refrained from participating in the newly established League of Nations, and no attention was paid to the American proposal on the issue at the conference.

In April 1920, the Allied Supreme Council granted mandate over Palestine to Britain and in 1922 the British Mandate was confirmed by the League of Nations. This was possible because of the active campaign by international Zionist leaders in favor of Britain. Zionists were also able to secure a fellow Zionist, Herbert Samuel, as the first British High Commissioner to Palestine. Weizmann is reported to have said later that, "I was mainly responsible for the appointment of Sir Herbert Samuel to Palestine. Sir Herbert Samuel is our friend. At our request he accepted that difficult position. We put him in that position. He is our Samuel" (Taylor 1959: 30). The League incorporated most recommendations of the Balfour Declaration and facilitated Jewish immigration from various parts of the world to Palestine. It also recognized Zionist organizations as legitimate institutions in achieving this goal. As soon as the indigenous Palestinians realized the Zionist designs and found that some of the leading British officials, in fact, not only belonged to the Jewish faith but a number of them were totally committed to the Zionist ideology, they began to oppose the Jewish migration to Palestine. This triggered the rise of Palestinian nationalism. On their part, the British authorities, which by then had received the League's Mandate to govern the land of Palestine, were caught in the middle. Although the British attempted to restrict Jewish migration to Palestine, the indigenous population continued to view the British Mandate authorities as a party in the conflict that favored Zionist aspirations. This perception became 
stronger because some Zionist leaders in Britain were able to achieve many of their objectives through their personal contacts.

Meanwhile, the Zionists had begun to capture lands from the indigenous Palestinians by smuggling arms to the territory with the support of international Jewish financiers. Soon, the Palestinians began to view heavy Jewish migration as something that was being imposed on them by the Mandate authorities at the expense of their fundamental rights. This convinced many British politicians, particularly lower ranking British officials working in Palestine, about the double standards of their government. Yet, Zionist leaders were able to continue the migration process through their connections with higher ranking officers and politicians in Britain. By 1930, the number of Jews in Palestine reached to nearly 156,000. Yet, the Zionist extremists were not satisfied with what they perceived as a slow flow of immigration. With the rise of ultra-nationalist sentiments in Germany, more Jews wanted to migrate out of the country and the pressure on the Mandate authorities increased to allow them into Palestine. A group of Zionists now under the leadership of Vladimir Jabotinsky, a follower of Italy's Mussolini, formed the New Zionist or Revisionist Organization to endorse more Jewish immigration into Palestine. On the one hand, these revisionist Jews would provoke the local population to stand against the British while, on the other, they would create pressure on the British to take action against the local population.

In order to create more room for the newly arrived Jews, by 1935, the Zionist activists openly resorted to terrorism in Palestine by attacking Palestinian villagers, forcing them to flee and create space for Jewish settlements there. They also organized financial and diplomatic support for such activities internationally. Incidentally, World War II brought more fortune to the Zionist cause and more devastation to the Palestinians. According to one Israeli author, "the world war served the Palestinian Arab cause ill... Palestinians, having just been crushed, became identified with the Axis cause." ${ }^{4}$ Britain allowed the Zionists to establish a regular army battalion for the support of the Allied forces during World War II. As the pressure increased on the Jews in Nazi Germany, demands were made to allow more Jews into Palestine. As a result, the Zionists began to confront British troops to illegally force European Jews into the country. Slowly, Zionists now turned toward the United States for support on humanitarian grounds. ${ }^{5}$ They induced President Truman to join the chorus with an appeal for more Jews to be allowed to enter into Palestine. It should be pointed out here that the indigenous peaceful protests against Jewish migration to Palestine were brutally suppressed by the British Mandate administration. With increasing pressure from world Zionists, the British administration became extra supportive of the Zionist cause.

Zionist militancy gradually received legal recognition. As soon as World War II broke out, Weizmann expressed the readiness of the Jews to stand by the British and demanded that independent Jewish military units to be created as part of the Allied armies in the Middle East. In principle, the British approved the idea, but as a "benevolent colonial power", it made the same offer to the Palestinians as well. For most Palestinians, however, Britain was not a just and benevolent power; rather it was a European colonial power that was assisting immigrants to steal Palestinian lands. As a result, there was no Palestinian response to the British offer. The Zionists initially joined the British military formations, and by 1944, an independent Jewish brigade was established. This provided the Zionists an opportunity to independently control weapons. With funding from international Jewish organizations, the 
Zionists formed armed organizations known as the Haganah, Irgun, Lehi and Stern Gang to terrorize the Palestinian villagers in various parts of Palestine to make room for the increasing number of Jewish immigrants; mostly arriving from Nazi Germany and Eastern Europe. Although the British administration declared these groups illegal, by then, the armed Zionist organizations were strong enough to take even the British to task. Their attempt to kill the British High Commissioner failed, but they were able to assassinate Lord Moyne, the British Minister for the Middle East. ${ }^{6}$ This caused enormous strain in the relationship between British Zionists and the British government. As noted earlier, however, the Zionists had already begun to concentrate their attention to the United States instead of Britain.

The American Zionists began to adopt a higher profile within international Zionism following a meeting of the American Zionist Organization on May 1942, which called for the establishment of a Jewish state embracing the whole of Palestine. By 1944, the Zionists were able to advance a resolution in both the US House of Representatives and the Senate - calling for unrestricted Jewish immigration to Palestine, which, they claimed, would become a "free and democratic Jewish commonwealth." More Jewish immigration into Palestine was necessary because the number was too low for the Jews to claim the whole of Palestine as their homeland, while the Palestinians constituted an overwhelming majority of the population in the territory. Although the Zionist aim failed because of a last minute intervention by then Chief of Staff, General George Marshall, the Zionists continued to manipulate the US policies in favor of a Jewish state and unrestricted Jewish immigration into Palestine. In August 1945, the Zionists succeeded in having President Truman appeal to the British prime minister for immediate admission of 100,000 more Jewish refugees into Palestine. The British reluctance to accept such an unrealistic and unjustified demand now faced, however, Zionist anger against them. In December 1946, at the World Zionist Congress in Basle, the American Zionists declared the British rule in Palestine illegal. By then, Britain had already lost power in the ground to effectively respond to such an ultimatum.

In 1948, under chaotic circumstances, the British Mandate authorities withdrew from Palestine and immediately the Zionists - mostly immigrants arrived since 1918 - declared the establishment of the State of Israel. Within hours, the United States recognized it, although the Secretary of State, General George Marshall (founder of the famous Marshall Plan for the post-war re-construction of Europe), vehemently opposed the idea. Between 1918 and 1948, a significant demographic shift had occurred in Palestine. In 1918, the number of Jews in Palestine was about 55,000 and in 1948, the number increased to about 646,000. In terms of ratio within the total population of Palestine, they increased from about 5\% to $31.7 \%$, but in terms of land possession, the Jews increased their portion from $2 \%$ to $6.5 \%$ during the same period (Saleh 2001: 43). Now that it had the military and political might, Israel started an aggressive ethnic cleansing campaign against the local population to create more room for existing and potential new immigrants. The Israeli army simply attacked unarmed Palestinian villagers and forced about 800,000 Palestinians out to Jordan, Syria, Lebanon, and other neighboring Arab countries. The most famous among these attacks was the one that targeted Dair Yasin, a village on the outskirts of Jerusalem, committed on the night of April 9, 1948. ${ }^{7}$ Palestinians call these events the "al-Nakba" or catastrophe. 
As a result, not only did the Palestinians become more militant in defending their territory, but sympathizers from neighboring Arab countries also joined them. Thus, with the establishment of the State of Israel, the Palestine crisis became a very critical issue for international peace and security. A few neighboring Arab countries also declared war against Israel in support of the Palestinian people, but the combined Arab forces were no match for the more experienced (due to their participation in World War II) and well-armed Israeli forces. The Arab armed forces performed very badly in the war. The issue was then referred to the United Nations. We shall discuss the role of the UN in this crisis, but before that, we would like to highlight the growth of Palestinian nationalism during the same period.

\section{The Early Development of Palestinian Nationalism}

As opposed to most other Afro-Asian and Muslim countries where nationalism emerged in response to European colonialism, nationalism in Palestine developed in response mainly to Zionism, and partially to the British administered League of Nations mandate authority. As soon as the Jewish Colonization Association was established to acquire lands in Palestine, "a group of Muslim and Christian notables cabled Istanbul urging the government to prohibit Jewish immigration and land purchase" (Lesch 2001). Although this particular act had nothing to do with the growth of Palestinian nationalism, such Zionist activities slowly contributed to the rise of Palestinian nationalist consciousness among the local population.

Here, one must note certain fundamental differences between the newly immigrant Jews and the local Palestinian population. While the Jews were highly organized, western educated, and diplomatically advanced to negotiate with the British Mandate authorities, the Palestinians were inefficiently organized, tradition-oriented, and politically inexperienced. Nearly 73 percent of the Palestinian population lived in rural areas. There was no organization or institution such as the World Zionist Organization or the Jewish Agency to support the Palestinians. In addition, it should be noted that there was no funding for their activities like those of international Jewish financiers who helped found the Kibbutz communities and other similar agricultural Jewish settlements. Palestinians did not seem concerned about the contradictory British commitments regarding their territory made to the Zionists (the Balfour Declaration), or to Sharif Hussein (the Hussein-McMahon Correspondence), or to the French with the Sykes-Picot Agreement. When, however, the Balfour Declaration was adopted as the official position of the British Mandate authorities and the League of Nations further endorsed it in 1922, the Palestinians became alarmed. They organized protest marches against the declaration in main urban areas such as Jerusalem, Jaffa and Haifa. As Palestinian protests continued, the British authorities became concerned when they began to see such a show of national unity. Soon the administration banned protest marches and street demonstrations.

In response to the British action, Palestinian leaders responded with a non-violent, nonconfrontational approach: they developed programs for educational, humanitarian and social welfare activities and continued to express their opposition towards Jewish immigration to their homeland. Here one may recall that the Zionists had begun such activities in the area much earlier. The native Palestinians soon realized an increasing divide between themselves 
and the immigrant Jews. One Palestinian leader, Mufti Amin al-Hussaini, initiated a program for the Palestinians. According to his biographer, he...

[E]stablished a Muslim orphanage of 160 girls and boys, supported schools such as Rawdat al-Ma'arif (which had 250 students with a scout organization attached to it), repaired the Nahawiyya School building within the Haram al-Sharif and established a library and museum there, imported 50,000 trees to plant on waqf land, expanded welfare and health clinics, and renovated numerous local mosques and other buildings (Mattar 1988: 29).

Like the Zionists, an international campaign was launched to fund these projects. The Mufti collected donations from Muslims all over the world including from Makkah during the Muslim hajj. This was a clear demonstration of the attachment of Muslims from other parts of the world to Jerusalem and Palestine. Unfortunately, the competition between the Palestinians and the Zionists did not remain limited to these humanitarian and educational issues for long. The situation began to dramatically change with the arrival of massive numbers of immigrants and the snatching of lands from the local communities.

Peaceful coexistence did not seem to be a part of the Zionist agenda; they wanted to change the demographic composition of Palestine by expelling the local population and filling the territory with immigrant Jews from various parts of the world. This was necessary in order to convert Palestine into a Jewish state, the ideological foundation of Zionism. Therefore, with the aim of making room for more immigrants, they would provoke the indigenous population to react against the existing settlers, and as a result, the British would take action against the Palestinians and through cunning and secretive manipulations, the top officials in London would be persuaded to allow even more immigrants into the territory. ${ }^{8}$ Interestingly, although the British were aware of the injustices committed against the local Palestinian population, the high level officials ignored the consequences of such acts, and the lower level officials were simply frustrated. ${ }^{9}$ According to one historian, "[m]any a British official who initially was not prejudiced against the Jews became anti-Semitic after a tour of duty in Palestine" (Lenczowski 1962: 381). And to cite an example of the attitude of the high officials, one may cite Arthur Balfour who is quoted to have said, "We had not been honest with either French or Arab ... it was now preferable to quarrel with the Arab rather than the French" (Mattar 1988: 15). Following every critical event, the British administration in Palestine established a commission, usually composed of middle ranking officials, to investigate and prepare a voluminous report only to be rejected because of manipulations by the Zionists. ${ }^{10}$ By the late 1920 s, however, the Palestinians began to actively protest against what they perceived as gross injustices committed against them. As a result, they would be increasingly isolated from political and negotiated settlements of the issue.

The growth of nationalism in Palestine was also different from others in the colonized territories. Generally, the British colonial officials patronized the growth of local nationalism as a part of the so-called "white man's burden" intricacy. ${ }^{11}$ The situation in Palestine was different however: it allowed the growth of some institutions, but bungled with others. This made the Palestinian experience unique in British colonial history. Like most colonies, Britain allowed Palestinians to establish the Supreme Muslim Council in 1921 to take care of religious schools and courts, mosques, orphanages and other similar organizations and 
institutions by administering waqf (endowment) properties in the area. Earlier, the Istanbulbased office of the Shaikh al-Islam was responsible for these institutions. That is why the position of the Mufti of Jerusalem became important in Palestinian politics. Initially the British allowed the Supreme Muslim Council and its leader Mufti Amin al-Husseini to serve Palestinian interests, but soon they developed differences as the Mufti began to assert rights of the Palestinian people. As for the Mufti, "the increase in Jewish immigration - 4075 in 1931,9553 in 1932, 30,327 in 1933, 42,359 in 1934, and 61,854 in 1935 - highlighted the bankruptcy of such moderate methods as petitions, delegations, and demonstrations" (Mattar 1988: 64). Peaceful methods of presenting Palestinian demands were rejected by the British. The Mufti's proposal for "some form of legislative government" with proportional representation with the veto power of the British High Commissioner was turned down even though similar systems were introduced in other colonies earlier. The British continued to follow its traditional "divide and rule policy" by attempting to create a loyal opposition among the Palestinians.

By the mid-1930s, a number of political parties emerged with claims to represent Palestinian interests. These parties were the Palestine Arab Party, the National Defense Party, the Reform Party, the National Bloc, the Nationalist Youth Congress, and Istiqlal or the Independence Party. In 1936, these parties were united under the Arab Higher Committee with the Mufti as its president. The Committee demanded: a) complete halt to Jewish immigration; b) prohibition of the transfer of Arab lands to Jews; and c) establishment of a national government. The British, however, continued with the colonial divide and rule policy by bribing and creating divisions among the Palestinians. As a result, extremism began to grow among the Palestinians. As the mediating power between the Palestinians and the Jewish immigrants, the British established a number of committees and commissions and issued "white papers" by defining the roles and spheres of influence of the conflicting parties. The more concessions that were given to the immigrants, however, the more they became aggressive to further their demands. And the immigrants were supported by the financial giants of international Zionism. As a result, Palestinian leaders such as Mufti Amin alHusseini, who began his career as a modest and non-violent imam, became an anti-British revolutionary. Some Palestinians had already turned militant by that time. Since the Zionists were using the power of arms to promote and settle immigrants, one Palestinian leader, Izzuddin al-Qassam - "a deeply religious shaykh and a man of integrity, social concern, and eloquence" - called for the Supreme Muslim Council to use the income from waqf properties in arming the Palestinians against the Zionists (Mattar 1988: 67). Al-Qassam himself was killed in an operation by the British police, but only to become a symbol of future resistance against Zionism in Palestine. ${ }^{12}$

In spite of Palestinian opposition, in a 1937 royal commission report, the British proposed the partition of Palestine between the Palestinians and the Zionists. This was unacceptable to the Palestinians since they wanted a united multi-religious democratic Palestinian nation. It should be noted that the Palestinians did not demand the expulsion of the Jews who had arrived in Palestine until then; they simply wanted to stop further immigration. The Zionists and the British Mandate authorities, however, seemed to have been cooperating. The Zionist leadership accepted the report immediately (with reservations about the number of Jews to be allowed in Palestine) as a basis for negotiations, while the 
Palestinians rejected it outright. For Palestinians, the establishment of a state in their homeland, composed mainly of European Jews, constituted a "robbery of their lands in broad daylight". As such, the Palestinians reacted angrily to the partition plan and began to demand the complete withdrawal of the British forces from Palestine. The British, on their part, identified the Palestinian reaction as an Arab rebellion and responded not only by removing the Mufti from his position as President of the Supreme Muslim Council, but also issued an arrest warrant against him. Arrest warrants were also issued against a number of other members of the Arab Higher Committee. As a result, most Palestinian leaders, including the Mufti, went into exile. On the ground, the British authorities continued to suppress the Palestinians. The British also tried to create groups among the Palestinians who would accept the partition plan, but failed. Failing to control the Palestinian uprising, Winston Churchill approved a kidnapping and assassination order of the Mufti (Mattar 1988: 81-82). The British-Zionist coordination now reached to the extent that they assigned an extremist Zionist to accomplish this mission. The Indian nationalist leader, M.K. Gandhi, observed these developments in Palestine as follows:

Palestine belongs to the Arabs in the same sense that England belongs to the English or France to the French... What is going on in Palestine today cannot be justified by any moral code of conduct... If they [the Jews] must look to the Palestine of geography as their national home, it is wrong to enter it under the shadow of the British gun. A religious act cannot be performed with the aid of the bayonet or the bomb. They can settle in Palestine only by the goodwill of the Arabs... As it is, they are co-sharers with the British in despoiling a people who have done no wrong to them. I am not defending the Arab excesses. I wish they had chosen the way of non-violence in resisting in what they rightly regard as an unacceptable encroachment upon their country. But according to the acceptable canons of right and wrong, nothing can be said against the Arab resistance in the face of overwhelming odds. ${ }^{13}$

Palestinian militancy against the British occupation reached a climax by the middle of 1938 when the British struck back with "squadrons of airplanes, the police force, the TransJordanian frontier forces, and 6,000 Jewish auxiliaries" (Matter 1988: 83) and the so-called Arab rebellion was brought under control by force. Like a "benevolent colonial power", however, soon the British government issued a White Paper (1939) declaring its intention to create a unified state of Palestine within the next ten years where limited Jewish immigration and transfer of land to Jews would be allowed only in certain designated areas. The White Paper made no mention about the proposed Jewish state. This time, the Palestinian leadership accepted the proposal of the White Paper immediately, but the Jewish leadership was disappointed. For reasons unknown, the then Defense Minister - Winston Churchill blocked the White Paper proposal. In reality, this effectively blocked the establishment of the Palestinian state.

The situation changed dramatically during World War II. Failing to control the Zionist militancy, a confused British leadership handed over the question of Palestine to the newly formed United Nations. Meanwhile the Arab League (founded in 1945) undertook the responsibility to pursue the Palestinian nationalist cause and formed a committee with the Mufti at its head. 


\section{The Palestine Issue at the United Nations}

According to one Israeli author, the Palestinian question was taken to the UN in February 1947 without stating who would take the issue to the world body. The historian believes that in accordance to the first article of its Charter, the UN was supposed to solve all international crises, and that is why the world body undertook the issue (Pappe 1994: 16). Under the UN Charter, however, any issue must be taken to the UN by a member state. In addition, it should be noted that in 1947, the conflict in Palestine was not yet an international one. In 1946, the UN adopted a resolution on the refugee problem in the region without mentioning the organization's potential role in resolving the conflict. Theoretically, with the dissolution of the League of Nations, the term of the British Mandate authorities was over. With the increasing number of deliberate attacks on the British troops and on the local population by Jewish militia groups, however, the Britain proposed a joint British-US committee to handle the issue. The US slowly began to get involved in the Palestinian issue. When the committee was formed, a number of its members turned out to be sympathizers of Zionism (Lenczowski 1962: 390-391). Then, on 2 April 1947, Britain formally requested a UN General Assembly session to consider the question of Palestine, although in a somewhat similar situation in India around the same time the British decided to divide the country between the conflicting parties.

The UN formed the United Nations Special Committee on Palestine (UNSCOP) to deliberate on the issue: No Arab country was included; only one Muslim-majority country Iran - was in the Committee. When the Committee invited both parties to present their cases, the head of the Jewish Agency's office in New York highlighted the Jewish contribution to humanity and civilization and argued for freedom and independence of the Jewish people. Although the Mufti - as Chairman of the Arab Higher Committee - would have been the most qualified person to represent the Palestinian case, a lawyer from Jerusalem and a member of the same committee - Henry Cattan - was selected by UNSCOP to represent the Palestinians. In his argument, Henry Cattan emphasized the injustices encountered by the local population at the hands of the British and the Zionists and called for an independent and democratic Palestine. Since the Jewish representative insisted on the establishment of the Jewish state, the Committee decided to investigate public opinion in Palestine. It should be recalled that following World War I, President Woodrow Wilson had undertaken one such investigation and the American King-Crane Commission rejected the idea of a Jewish state in Palestine outright. This time, however, the UNSCOP came up with two plans: one known as the majority plan prepared by mostly Western countries proposing to divide the land between the Jews (over $56 \%$ of the territory for about $31.7 \%$ mostly immigrant population) and Palestinians (about $43 \%$ of the territory and Jerusalem would be a neutral international city under direct supervision of the UN). The other known as the minority plan backed by India, Iran and Yugoslavia advocating a federated state composed of two component states, each of them enjoying local autonomy with Jerusalem as its capital. The Palestinians somehow reluctantly accepted the minority plan (though they actually wanted a unitary state with democratic rights of every citizen in the territory) while the Zionists, also reluctantly (they wanted the whole of Palestine as a Jewish state) favored the majority plan. When the proposals were put forward for discussion, however, the Zionists vigorously embarked on 
gathering international support for the majority plan. One American observer describes the Zionist activities on the UN resolution as follows:

Rallying a group of influential Americans and selecting their targets with care, they exerted all possible influence - personal suasion, floods of telegrams and letters, political and economic pressure... Many of the telegrams, particularly, were from Congressmen, and others as well invoked the name and prestige of the United States government. An ex-Governor, a prominent Democrat with White House and other connections, personally telephoned Haiti urging that its delegation be instructed to change its vote (Roosevelt, 1948: 15-16).

The Zionists also targeted Liberia, China, the Philippines, Ethiopia and Greece. In support of this observation, one US government report noted the situation as:

The US and USSR played leading roles in bringing about a vote favorable to partition. Without US leadership and the pressures which developed during UN consideration of the question, the necessary two-thirds majority in the General Assembly could not have been obtained... It has been shown that various unauthorized US nationals and organizations, including members of Congress, notably in the closing days of the Assembly, brought pressure bear on various foreign delegates and their home governments to induce them to support the US attitude on the Palestine Question (Cattan 1988: 36).

On 29 November 1947, the UN adopted the majority plan to divide Palestine on conditions that Israel recognizes the right of the Palestinian refugees to return to their original homes and both states maintain an economic union. ${ }^{14}$ The UN resolution also noted that Britain would withdraw from the country by August 1948 and a five-member UN Commission would supervise the division of Palestine. The Palestinians were extremely disappointed and rejected the plan. The Arab states observed that the resolution had violated the UN Charter and they also rejected the planned partition.

As soon as it was clear that the British were leaving the territory, Jewish and Palestinian armed groups began to clash for territorial control. As a result, Britain decided to terminate its mandate and leave Palestine even earlier than envisaged. Britain set May 15 for withdrawal, but on May 14, a day earlier, a group of Jewish activists in Tel Aviv proclaimed the establishment of Israel in Palestine. Within hours, the US and the USSR recognized the new state, and other western countries followed suit. Muslims on the other hand reacted angrily toward the US. ${ }^{15}$ Immediately, an all-out war broke out between 75,000 strong Israeli armed forces and numerous disorganized Palestinian groups. Although volunteers and regular armies from neighboring Jordan, Egypt, Syria, Iraq and Lebanon entered in support of the Palestinians, as mentioned earlier, they were no match for the technologically more advanced and better equipped Israeli troops. The Israelis had acquired arms, munitions and even airplanes from European countries and had smuggled many weapons into Palestine despite a UN ban on arms shipment to the region. Israel was also supported by Jewish volunteers, some with military training and World War II experience, from various parts of the world.

Meanwhile the UN continued with its effort to end the violence and on 20 May 1948, the Security Council appointed Count Folke Bernadotte, the president of the Swedish Red Cross who enjoyed the reputation of negotiating with the Nazis and saving many Jewish 
lives, as the UN mediator for Palestine. The UN also established the United Nations Truce Supervision Organization (UNTSO) to help mediate between the conflicting parties in Palestine. Bernadotte was ordered to "promote a peaceful adjustment of the future situation in Palestine" and was allowed to negotiate beyond the terms of the original Partition Plan. Bernadotte recommended certain modifications to the Plan by slightly reducing the size of the Jewish occupied territories. The next day, on 17 September 1948, he was assassinated by a Jewish terrorist group in Jerusalem. No action was taken against those who were identified as Bernadotte's assassins. In fact, one of the accused, Yitzhak Shamir, was later elected as Israel's prime minister. This clearly indicated the limitations the UN was going to have in handling the issue. It is noteworthy that since the establishment of the State of Israel through the direct intervention of the UN, the former has developed an antagonistic attitude towards the world body. ${ }^{16}$ By the middle of 1949 , the war stopped and military might determined the future of Palestine; Israel occupied almost 78 percent of the historical territory, Egypt occupied Gaza and the Jordanian forces occupied central and eastern parts of Palestine which came to be known as the West Bank.

On 29 November 1948, Israel applied for UN membership but this was rejected because of lingering questions over its boundaries, the status of Palestinian refugees and the legal status of Jerusalem. When it re-applied in February 1949, the Secretary General held discussions on those questions, and after having assurances from the Israeli authorities, the country was granted UN membership on 11 May 1949. One must note that the process of Israel's UN membership differed from that of all other members of the world body.

\section{Later Developments in Palestinian Nationalism}

Palestinian national identity was the primary victim of the 1948 War. The most active members of the Arab Higher Committee were banned from Palestine since the beginning of World War II and therefore there was no formal representation inside Palestine. Although the Palestinians generally favored the 1939 White Paper proposals - but because all Palestinian leaders were in exile - following World War II, they began to advance their demands through the office of the Arab League. When the war broke out in 1948, the Palestinian leadership was in total disarray and the presence of a number of national armies complicated the issue further. The Mufti was not in favor of the direct involvement of other Arab armies; he wanted, like the Zionists, financial, military and humanitarian support from other countries. When the war broke out, however, there was not only no unified military command against Israel, but the Egyptian and the Jordanian governments had their own agendas on the future of the Palestinian territories.

In an attempt to organize the Palestinian efforts, through the support of the Arab League and the Egyptian government in July 1948, an All-Palestine Government was formed in Gaza with an 86-member constituent assembly. Jordan refused to recognize this new Palestinian government, however. During the war that followed, Jordanian troops commanded by British officers - occupied east and central portions of Jerusalem. Egyptian troops retained control over Gaza and Palestinian forces were completely routed by the Zionists. In this context, the short-lived Palestinian Government slowly disappeared. Jordan renamed its occupied part of Palestine the "West Bank," and thus the political entity of 
Palestine seemed to have vanished from the landscape. Pro-Israeli journalists and academics began to argue that a Palestinian nation never existed in history and the question of its existence did not arise until our present time. They also argued that the Palestinians should find refuge in Jordan, an artificial state that the British had recently created.

Emotional attachment to Palestinian nationalism resurfaced within a few years after the 1948 War because of the Palestinians' strong desire to regain their fundamental right to existence - which was recognized in the UN Declaration of Human Rights (1948) and by international law. Although some neighboring Arab countries attempted to define the Palestinian struggle as an Arab nationalist struggle, because of the existence of many Arab countries, with the passage of time, their attempts failed. Palestinian freedom fighters continued their struggle by attacking Israeli targets from adjacent Gaza and Jordan. In retaliation to those strikes, Israel not only destroyed the Palestinian targets, but also massacred the complete civilian infrastructure and support base of all peoples living in the area. As a result, both Jordan and Egypt became increasingly reluctant to allow the Palestinians to continue their guerilla activities against Israel. Slowly, the Palestinians realized the need for more organized efforts to achieve their goal of liberation. The Arab League had undertaken the responsibility to pursue the Palestinian cause, but because of opposition by some notable member countries, they were not able to deliver any effective results. Consequently, a number of Palestinians living in Kuwait, inspired by the freedom fighters in Algeria, established the Fatah in 1957 with the aim of freeing Palestine from foreign occupation. Around the same time, some Palestinian students studying at the American University of Beirut founded the Arab Nationalist Movement with the same goal. This was followed by the formation of a number of other small organizations with similar objectives.

On 28 May 1964, the Fatah, Popular Front for the Liberation of Palestine, Democratic Front for the Liberation of Palestine, the Front for the Liberation of Palestine, Saiqa - the Army of the Liberation of Palestine, the Palestinian communities in the diaspora, and some prominent Palestinians, met in Jerusalem and established the Palestine Liberation Organization (PLO). A 430-member Palestine National Council comprising representatives from all spheres of life was also established. In June 1964, the Arab League recognized the PLO as the only legitimate representative of the Palestinian people. Thus, a new journey for Palestinian nationhood began. Palestinian nationalism received a further boost in 1969 when the OIC was established in response to an arson attack on the al-Aqsa mosque in Jerusalem under Israeli occupation.

\section{The Palestine Issue and the Role of the OIC}

The OIC declared in its Charter that it would "co-ordinate efforts to safeguard the Holy Places [in Jerusalem] and support the struggle of the people of Palestine and to help them regain their rights and liberate their land" (Article II A-5). Israel had occupied Jerusalem in a war in 1967 and the OIC, in numerous resolutions, expressed its strong resolve to free Jerusalem and the rest of Palestine from foreign occupation, adopting a strategy for Israel to implement the UN resolutions. The OIC declared jihad against Israel and opened an office in 
its headquarters in Jeddah ${ }^{17}$ to coordinate Palestinian military activities against the latter. It also declared jihad in the areas of diplomacy and economics to promote the Palestinian cause. In reality, however, the OIC encountered an internal problem in handling the Palestinian question: Since 1948, when Jordan had captured the west bank of Jordan River, the Palestinian political entity ceased to exist. The historical Palestine was partly occupied by Israel, partly by Jordan, and the latter began to call its part the "West Bank." This brought the Palestinian freedom fighters in direct conflict with Jordan. In this context, it should be recalled that in 1948, when an All-Palestine Government was formed with the blessing of the Arab League, Jordan had strongly opposed the new government. By 1970, the Palestinians and the Jordanian armed forces fought a number of skirmishes, and by the end of the year, the conflict reached to new heights. It was then that King Faisal of Saudi Arabia and President Abdul Nasir of Egypt intervened using the platform of the OIC and the Arab League. The conflict was resolved when Jordan renounced its desire to represent the Palestinians and the PLO agreed to move out of Jordan. Palestinian nationalism triumphed and the PLO moved its head office to Lebanon. By 1974, the Palestinian National Council began to moot the idea of a two-state solution: they gave up the idea of a democratic Palestine with Christians, Jews and Muslims living together in a homeland. They also indicated that they would be satisfied with the pre-1967 borders or only 22 percent of historical Palestine. This was a major concession on the part of the Palestinians; a land they considered their own, now they were prepared to accept only 22 percent of that ancestral territory. They confined their demands only to the city of Jerusalem and the right of the refugees to return: two demands generally recognized by the international community and international law. As a result, slowly, many countries around the world recognized the PLO as the only legitimate representative of the Palestinian people, and many countries established diplomatic relations with them. The PLO also became an observer at the UN General Assembly.

On its part, Israel became even more active in denying the Palestinians their rights and in establishing its legitimacy as a Jewish state. In this mission, Israel defeated not only the Palestinians, but also all the OIC countries put together. The Palestinian gestures of concessions, such as accepting only 22 percent of original Palestine, were totally ignored by the Israelis. The OIC's only success was to get the PLO an observer status at the UN and to adopt a number of non-binding resolutions at the UN General Assembly, including one that declared Zionism a racist ideology in 1975 - which was later rescinded in 1991. In the general conflict between Zionism and the Palestinians, however, Israel has been able to not only to keep the PLO from the lands in Palestine, but also to create division within the OIC. Egypt was induced to break away from the OIC and the Arab League ranks to establish peaceful relations with Israel in 1978. In response to Egypt's unilateral approach toward Israel, in a statement, the OIC declared the agreements between Egypt and Israel as "a blatant departure from the Charter of the Organization of the Islamic Conference and a violation of international law and the United Nations resolutions." It declared its decision to "suspend the membership of the Arab Republic of Egypt to the Organization of the Islamic Conference and all its agencies and bodies up to the time when the reasons that provoked this suspension are eliminated (OIC Resolution 8/10-P). The OIC also urged all member states to sever all diplomatic and economic ties with Egypt. Most of the OIC member countries followed this recommendation. 
Within a few years, however, the OIC changed its position and took Egypt back to its fold with no explanation. The Egyptian president claimed that his country had always been committed to both the OIC Charter and the Palestinian cause, and was not responsible for Egypt's expulsion and re-admission into the organization. ${ }^{18}$ In the process, the Palestinian cause suffered. The OIC, in fact, deceived the Palestinians by declaring its "jihad" against Israel through establishing the Al-Quds Committee headed by the King of Morocco. It proclaimed the desire to "undertake in all Islamic countries a psychological mobilization of the people through official, semi-official, and popular uses of the mass media" and inviting member states to open offices for volunteers, "wishing to participate in the jihad for the liberation of the holy land." In reality, the Muslim-majority countries left the Palestinians alone to fight Zionism and Israel. When the PLO first launched its struggle against Israel in the 1960s, the Egyptian president, Abdul Nasir, banned its activities from Egyptian territories because by providing the PLO a home, Egypt had become subject to Israeli aggression. Later, President Anwar al-Sadat completely left the PLO, defied the OIC resolutions and signed a peace agreement with Israel - abandoning ideas of Arab and Islamic brotherhood when they clashed with what was perceived by the government as Egyptian national interests. Similarly, Jordan sought to get rid of the PLO in 1970. On their part, Syria, Libya and Iraq went further in protecting their "national interests" in Middle Eastern politics by creating their own factions within the Palestinian population. In short, most of the OIC countries remained unconcerned throughout the PLO's struggle against Israel even at the very critical moment in 1982 when Israel invaded and expelled the PLO out of Lebanon. The PLO Chairman described the situation as follows, "It [PLO] was besieged for 88 days in Beirut while no one extended any help or support. It was then besieged in Tripoli (South Lebanon) - a joint ArabIsraeli blockade while neither Arab nor Muslim moved a finger". ${ }^{19}$ Yet at the end of the Fourteenth Foreign Ministers Conference of the OIC, held in December 1983, the Chairman of the Conference officially cabled the PLO Chairman saying:

On behalf of the delegates of the $14^{\text {th }}$ Islamic Conference of Foreign Ministers, I wish to reiterate and affirm that the struggle of the Palestinian people is our struggle. We speak with one voice in seeking a just and durable settlement of the Middle East crisis (alAhsan 1992: 117).

This inconsistency between words and deeds of the OIC leadership had serious consequences on the broader Muslim world. Muslim leadership seemed to have been interested in telling their people that they cared for fellow Palestinian Muslims as a mere political tool. This contributed heavily to the rise of extremism in the Muslim world. Yet most Muslim countries continued with their pro-Palestinian rhetoric.

\section{The Unremitting Deterioration of the Situation in Palestine}

The OIC duplicity has caused more difficulties for the Palestinians. The overall situation of the Palestinians living in occupied territories has constantly deteriorated. It is impossible for people living outside the territory to even conceive the levels of suffering, which include indiscriminate killing of unarmed civilians, arbitrary demolition of houses, and ruthless restriction of movement and lack of supply of essential goods even to hospitals. Yet Israel 
and its foreign allies have held Palestinians responsible for the deteriorating situation in the area. Since 1967, the so-called international community has developed an idea called the "land for peace," but it is difficult to understand what it means in reality. Theoretically, the idea has a serious implication: should the international community allow a country or a group of people to occupy another people's land by military might and then negotiate with the original inhabitants for grabbing parts of that land legally? In the context of the present conflict, Israel has never defined its borders and has been gradually occupying the entirety of the former British Mandate of Palestine.

Diplomatically, Israel has not stopped its efforts by convincing Egypt to recognize it as an official state; it has also designed a plan to end its international isolation. That would have been difficult, however, without having lured the Palestinian leadership to the same fold. Meanwhile two significant developments occurred: one, in 1987, a new wave of Palestinian uprisings known as the intifada (which literally means "shaking off") began; and two, in 1988, the Palestinian National Council adopted a new strategy by accepting the UN resolutions on the issue, which recommended a division of Palestine among the immigrant Jews and local Palestinians. Intifada meant Palestinian children throwing stones at armed Israeli soldiers, armored vehicles and tanks to express their dissatisfaction and disapproval of continued Israeli occupation of their land. Although this sounds ridiculous, this mass uprising shook the foundation of the Israeli regime. With this uprising and momentum, a new political movement called the Hamas emerged among the Palestinians.

As for the PLO, its new strategy to permanently give up claims over 78 percent of historical Palestine for the sake of peace made itself recognized as a legitimate political organization by Israel and the US. A process for peace began in 1991 with a European initiative which resulted in a deal in 1993. The role of the European initiative, however, was then assumed by the US. The Clinton administration brought the Palestinian leadership to sign an agreement (known as the Oslo Accord) with Israel. Under this agreement, the Palestinians were to be granted self-rule in the Gaza Strip and Jericho, which would include other Palestinian areas (occupied in 1967) later. It was also agreed that the final status of Jerusalem and "other sensitive issues" including the right of the Palestinians to return to their original homes would be settled within two years.

In reality, the Oslo process brought more suffering to the Palestinians. They were allowed to establish a political institution called the Palestinian Authority, but were denied the status of statehood. The Palestinian Authority received administrative responsibilities in parts of the territories claimed to be their own, but Israel maintained the power to enter into those areas at its will. In the name of security, Israel conducted military operations in the socalled self-rule territories, and the Palestinian Authority accused Israel of being involved in extra-judicial assassinations. According to one Jewish peace activist and author:

...Oslo had been much more about "process" than about peace. Living conditions and the economy had all seriously deteriorated throughout the Oslo years. Israel's military occupation had become increasingly harsh - closures preventing Palestinians from entering Israel were expanded to prevent travel within and between the West Bank and Gaza; military checkpoints proliferated throughout the "swiss cheese-style" maze of Israeli and partial Palestinian authority; house demolition continued; and settlement 
construction nearly doubled throughout the occupied territories since Oslo (Bennis 2002: $34)$.

The Oslo Agreement failed because Israel did not fulfill its obligations. On the other hand, the Palestinians were expected to keep quiet on however Israel treats them. In August 2000, the Oslo Peace Process totally collapsed. On its part, Israel benefited greatly from the Oslo Agreement, which was immediately followed by similar agreements between Israel and Jordan. A number of other OIC countries recognized and established diplomatic and commercial relations with Israel - which helped fuel an exceptional and accelerated growth of Israeli economy. This was a major success for Israel: after seventy years from the beginning of Jewish immigration against the will of the local population, at least some Palestinians and many Muslim countries were now willing to share their land, and interact. Israel, however, seemed to have had a different agenda altogether: It not only created more hardship for the Palestinians; but it also imported more Jews from different parts of the world to settle in Palestinian territories. By the end of 2000, the number of Jews in Israel increased to more than 4,947,000 while the number of Palestinians in the diaspora also reached to about 4,900,000. Israel also continued to accuse the Palestinians of starting fresh violence, and claimed that whatever they did was in response to Palestinian actions. ${ }^{20}$ Whenever the Palestinians demanded the presence of international observers to monitor these acts of violence, Israel opposed such moves. In this, Israel received unreserved US support, which encouraged the continuation of Israeli violence. This situation angered many people in the Muslim countries - turning a handful of them towards suicide activism; and Islamic radicalism began to take root in the Muslim world at a catastrophic proportion.

As soon as the Oslo Process collapsed, the Israeli leader Ariel Sharon provoked another Palestinian uprising known as the second intifada in September 2000. Apparently, for immediate political gains, Sharon entered into the holy sites in the al-Aqsa Mosque with armed guard - provoking spontaneous Palestinians protests. On the first day of protest, 5 Palestinians were killed by the Israeli security forces, and the next day 10 more were killed. Since then, thousands of Palestinians and many Israelis - including hundreds of children have lost their lives, and many more have been wounded in the ongoing conflict. ${ }^{21}$ In 2002 , Saudi Arabia's then Crown Prince, later King Abdullah, representing the Arab League and the OIC countries, came up with a proposal to establish "normal relations" with Israel in exchange of Israeli recognition of a Palestinian state with 22 percent of the original territory. Although this was a major concession on the part of Palestinians and Muslims around the world, Israel did not respond positively to the offer. The conflict continued. Since then, the Palestinians have captured and kept one Israeli soldier in their custody and the Israelis have detained 9,599 Palestinians in response. The Israeli authorities have also demolished 4,170 Palestinian houses and built over 60 new Jewish-only settlements in the occupied territories.

In response to continuous aggressive Israeli behavior, Palestinians have moved to harden their stand: in the 2005 elections, they abandoned the compromising PLO and elected Hamas to power, which took a stronger position in defending Palestinian rights. However, the Palestinian ability to stand against Israeli repression is extremely limited. Israel invades and fires upon Palestinians at will and has turned Gaza into an open-air prison by drafting Egypt for the job. Efforts of international peace activists to deliver even medicines to Gaza are 
heavy-handedly prevented. This year, in March 2018, the Gazans decided to protest their state of affairs by demonstrating at the Israeli border every Friday. The Israelis so far killed 214 individuals that included paramedics, children, women and elderly and wounded more than 18,000 . Why do the Palestinians do this? Why do they give their life so easily? In response, one may ask what other choice do they have? Occasionally they fire "rockets" to Israel, which the latter has used as an excuse to invade the Palestinian territories, but those have no impact on the ground except to tell the world that, "we also do exist." They simply wish to draw attention of the world community to the Israeli repression of Palestine.

The conflict continues to deteriorate everyday with reports of the killing of Palestinian civilians. An Israeli wall separating Palestinian localities and hundreds of checkpoints have made the life of Palestinians extremely miserable. In July 2018, Israel has declared itself an exclusive Jewish state, Hebrew as the official language and undivided Jerusalem as its capital. By implication, all Palestinians have become second-class people in their own native lands. Almost all recent studies on contemporary world situations suggest that the question of Palestine is the most critical one in international politics today.

\section{Is there a Solution to the Palestinian-Israeli Conflict?}

Unfortunately, no solution to the problem seems in sight primarily because of Israeli obstinacy. No matter what one wishes to believe or what the ancient history of the area may hint, records clearly suggest that the Palestinians have been living in the territory in question for thousands of years. Moreover, at the end of the $19^{\text {th }}$ century, when the ideology of Zionism emerged, Palestinians constituted more than 95 percent of the total population of Palestine. It is also a fact of history that the state of Israel has displaced the native population during the past half-century or so. Any solution to the problem must address this question first. Israel at one stage tried to push the Palestinians to Jordan, but that has not worked: Palestinian national identity has prevailed. Why should the Palestinians move to another country? After all, under international law, and common human values, the Palestinians have every right to re-claim their own homeland.

Whenever the Palestinians have demanded their rights to homeland, the Israelis and Western-dominated mainstream international media have raised the question of Israel's right to existence as if the Palestinians have denied that right. Israel has always been supported by the mainstream media as they accuse Palestinians of denying Israel's right to exist. Interestingly though the Palestinians have only demanded their own right to exist, not the total destruction of Israel. In reality, Israel has denied the Palestinians' rights as well as their right to exist. This is clearly reflected in the Israeli political rhetoric. Israel has always wanted only the Jews to inhabit the country while the Palestinians always demanded a united secular state with citizens from all religious affiliations. One international lawyer and author has put the question of Israel's right to existence as:

"Recognising Israel's existence" is not logical nonsense and appears on first impression to involve a relatively straightforward acknowledgement of a fact of life -- like death and taxes. Yet, there are serious practical problems with this formulation. What Israel, within which borders? The 55 per cent of historic Palestine reserved for a Jewish state by the UN General Assembly in 1947? The 78 per cent of historic Palestine occupied by Israel in 
1948 and now viewed by most of the world as "Israel" or "Israel proper"? The 100 per cent of historic Palestine occupied by Israel since June 1967 and shown as "Israel" on maps in Israeli schoolbooks? Israel has never defined its own borders, since doing so would, necessarily, place limits on them. ${ }^{22}$

Israel has also rejected the idea of any international mediation in the conflict. Although Israel has come into existence with the help of UN resolutions, it has flouted at least 65 or more UN resolutions. In 2009, Turkey had negotiated an understanding between the government in Gaza and Israel with some kind of "live and let live" scenario, but Israel destroyed the deal by invading the territory. The unconditional US support for Israel is another major obstacle barring any peaceful solution to the problem. During the past two decades, the US support for Israel has intensified so much that it is very difficult to get any resolution passed in the UN Security Council critical of Israel: to date, the US has cast at least 39 vetoes on UNSC resolutions criticizing Israel. The current Trump administration has surpassed all previous administrations in its support for Israel by declaring Jerusalem as Israel's capital.

\section{Concluding Remarks: The Relevance of the Palestinian Crisis for the Muslim World}

With the development of global communication, the question of Palestine has become more relevant to the universal Islamic ummah identity consciousness. There has been a direct relation between Zionist activism and the Muslim quest for unity. The greater the Zionist presence is, the higher the quest for unity among Muslims becomes. In 1931, the second conference of Mu'tamar-i- 'Alam al-Islami was held in Jerusalem in response to a crisis in the Wailing Wall. In 1969, another such conference of Muslim heads of states was held in Rabat, Morocco in response to the attack at the al-Aqsa Mosque in Jerusalem that led to the foundation of the Organization of the Islamic Conference. Since then, the 1973 War, the 1974 international oil embargo, the 1979 Islamic Revolution in Iran, current political situations in most Middle Eastern countries, particularly the catastrophic invasion and occupation of Iraq all have some relevance to the ongoing Palestinian crisis.

Muslim political leaders during the Cold War period understood this well. That is why in OIC resolutions they have expressed their unequivocal support for what they referred to as the "Palestinian cause". However, with the clash of civilizations thesis and the US War on Terror, the situation has changed significantly. On the one hand, extremists have found many reasons to turn violent not only against what they call "the West"; but also against those Muslim regimes who are known as pro-US in international politics. On the other hand, aggressive Israeli diplomacy has made inroads to many Muslim countries such as Egypt, Saudi Arabia, and the UAE. This has been possible because of the lack in transparency in the policy-making system of most of these authoritarian countries. This has enormously widened the gap between the ruling elites and the masses in Muslim-majority countries and the overall situation is becoming more volatile and catastrophic at our present time. 


\section{Notes}

1. Apparently, Emperor Napoleon I wished to exile them from France. For reference, see Saleh (2001: 22).

2. Jacob H. Schiff, a member of the American Jewish Committee during the War is reported to have said, "I believe that I am not far wrong if I say that from fifty to seventy per cent of the so-called Jewish Nationalists are either atheists or agnostics and that the great majority of the Jewish Nationalist leaders have absolutely no interest in the Jewish religion." Quoted in George Lenczowski (1962: 374-375).

3. Weisgal (1944: 131), Quoted in Taylor (1959: 10).

4. Morris (2004: 12). It should be noted that at time the Zionist leader Jabotinsky was actually maintaining close contact with and receiving assistance form the Italian leader Mussolini.

5. This provoked many Jews to argue that Zionism as an ideology was political not religious. See, for example, Irwin M. Herman (1962).

6. Among the Zionist terrorists of the time was Menachem Begin, on whose head the British Mandate authorities offered 100,000 British pounds, and who later became a democratically elected prime minister of Israel. He also won the Nobel Prize for Peace.

7. According to Jacque de Reynier, the Chief Delegate of the International Red Cross, on this occasion the Irgun led by Menachem Begin, massacred 300 men, women and children "without any military reason or provocation of any kind" (Cattan 1988: 44-45).

8. For the description of one such event, see Mattar (1988: 35-38).

9. The story of the British officials working in Palestine is rather little complex because they developed their opinions based on their specific experiences.

10. See, for example, the fates of Shaw (1929), Hope-Simon (1930), and Peel (1936) Commission reports.

11. For example, the Indian National Congress was founded by a British civil servant working in India.

12. Here one must note that the British failed in curbing militancy among the Zionists in a similar manner.

13. Quoted in The Origin of the Palestine - Israel Conflict, originally published by the Jews for Justice in the Middle East (Manila: Federation of Asian Bishops Conference, 2003), pp. 11-12.

14. Some influential Jewish leaders such as Herbert Samuel, the first British High Commissioner to Palestine, and J. L. Magnes, the first president of the Hebrew University of Jerusalem, strongly opposed the division plan of Palestine because the Arab part would not be economically viable.

15. Saudi Arabia, for example, denied a $\$ 50$ million loan from the US even though the country was in desperate need of cash at that time.

16. See, http://www.israel-un.org/israel_un/uneasyrelation.htm, the official site of Permanent Mission of Israel to the United Nations.

17. The OIC Charter declared its head office to be located in Jerusalem, but since the city was under Israeli occupation, the head office is temporarily located in Jeddah, Saudi Arabia.

18. For a detailed discussion on the subject, see Abdullah al-Ahsan (1992: 113-119). 
19. See "Arafat Renews his call for Jihad," in Arabia News Magazine (August 1984), p. 7.

20. On this subject see a Google video documentary titled: Peace, Propaganda and the Promised Land.

21. For current statistical and other information, see www.ifamericansknew.org. This site is run by mostly American Jewish peace activists.

22. See John V. Whitbeck, "Israel's immoral 'right to exist" in http://weekly.ahram.org.eg/2006/825/op14.htm.

\section{References}

Al-Ahsan, Abdullah (1992) Ummah or Nation: Identity Crisis in Contemporary Muslim Society (Leicster: Islamic Foundation). TARI).

Bennis, Phyllis (2002) Understanding the Palestinian - Israeli Conflict (Orlando, Fl:

Cattan, Henry (1988) The Palestine Question (London: Croom Helm).

Herman, Irwin M. (1962) Zionism is Political, not Humanitarian (New York; The American Council for Judaism). Yoseloff).

Herzl, Theodor (1960) The Complete Diaries of Theodor Herzl (New York: Thomas

Lenczowski, George (1962) Middle East in World Affairs (Ithaca, NY; Cornell University Press).

Lesch, Ann M. (2001) "Zionism and its Impact", in Washington Report on Middle East Affairs. See www.wrmea.com/html/focus.htm. Accessed on January 19, 2019.

Mattar, Philip (1988) The Mufti of Jerusalem: Al-Hajj Amin al-Husayni and the Palestinian National Movement (New York: Columbia University Press).

Morris, Benny (2004) The Birth of the Palestinian Refugee Problem Revisited (Cambridge: Cambridge University Press).

Said, Edward (1992) The Question of Palestine, New Edition (London: Vintage).

Saleh , Mohsin M. (2001) The Palestinian Issue: Its Background and Development Up To 2000 (Kuala Lumpur: Fajar Ulung).

Taylor, Alan R. (1959) Prelude to Israel: An Analysis of Zionist Diplomacy 1897-1947 (New York: Philosophical Library).

Tsur, Jacob (1969) Zionism: National Liberation Movement (Israel: At the Government Printing Press). 
Weisgal, Meyer W. (ed.) (1944) Chaim Weizmann, Statesman, Scientist, and Builder of the Jewish Commonwealth (New York: Dial Press).

Weizmann, Chaim (1949) Trial and Error: the Autobiography of Chiam Weizmann (New York: Harper).

John V. Whitbeck (2006) "Israel's immoral "right to exist" in http://weekly.ahram.org.eg/2006/825/op14.htm

\section{About the Author}

Abdullah al-Ahsan is Professor of Comparative Civilizations at the Department of Political Science and International Relations at Istanbul Şehir University, Turkey. He graduated from McGill University, Montreal, Canada, and the University of Michigan, Ann Arbor, Michigan, USA. Ahsan has published many articles on the relationship between contemporary Islamic and Western civilizations. His notable works include: The Organization of the Islamic Conference: Introduction to an Islamic Political Institution (International Institute of Islamic Thought, Herndon, VA, 1988) and Ummah or Nation: Identity Crisis in Contemporary Muslim Society (Islamic Foundation, Leicester, 1992). He has edited along with Stephen B. Young Guidance for Good Governance: Explorations in Qur'anic, Scientific and Crosscultural Approaches (International Islamic University Malaysia, 2008 and 2013). His latest edited book Qur'anic Guidance for Good Governance: A Contemporary Perspective (2017) has been published by Palgrave, Macmillan. His books and articles have been translated into Arabic, Bengali, Bosnian, Turkish and Urdu. 